\title{
An Investigation of Barriers to Females' Involvement in the Nigeria Construction Industry
}

\author{
Akinsiku O. E. ${ }^{1 *}$ and Ajala N. O. ${ }^{1}$ \\ ${ }^{1}$ Department of Quantity Surveying, Faculty of Environmental Sciences, University of Lagos, Lagos State, \\ Nigeria \\ Corresponding Author: *oakinsiku@unilag.edu.ng
}

\begin{abstract}
The continuous domination of the Nigeria construction industry by men remains an issue of concern to construction stakeholders as females in the Nigerian construction industry continue to be largely underrepresented. The objective of this study was to investigate the barriers to females' involvement in the Nigerian construction industry with a view to suggesting strategies that will assist to bridge this barrier. The survey reviewed literature on the level of female participation, the perceptions about women, the opportunities available to females and strategies of increasing the number of female participation in the industry. The instrument for data collection was obtained by the use of a survey questionnaire as well as the reviews of extant literature. The sampling method employed is stratified random sampling. The questionnaires were administered to built environment practitioners in consulting and contracting establishment in Lagos metropolis, Nigeria. The findings revealed that the barriers which influence female under-representation in the Nigerian construction industry include; the male-dominated structure of the construction industry, family commitments such as marriage and childbirth, masculine nature of the job, long working hours. The strategies recommended to bridge this barrier include the formulation of employment policies which prevent sexism, educating young women about the industry, providing better working conditions and flexible working policies for women, provision of incentives in order to attract more women into the Nigerian construction industry.
\end{abstract}

Keywords: Barriers, construction industry, discrimination, gender, recruitment

\subsection{Introduction}

The construction industry contributes immensely to any economy; it is the sector responsible for the provision of physical infrastructure that guarantee improvement in the economic and social needs of the people; it significantly contributes to the fulfillment of national goals (Shittu and Shehu, 2010). The Nigeria construction industry is next to the agriculture sector as regards its contribution to the Gross Domestic Product (GDP) and regarding the number of people it engages as the workforce. However, a significant issue confronting the construction industry is that of gender barriers and discrimination (Sang and Powell, 2012; Kharmalamova, 2013; Powell and Sang, 2013). This according to Adeyemi et al. (2006) leads to the substantial under-representation of women in the construction and engineering sectors. This issue of the poor representation of female in the construction industry is a concern among construction stakeholders. Previous studies posit that issues such as bad company policies with respect to recruitment and promotion, inadequate or unsafe working conditions, the tasks, the number and variability of hours worked, the monotony of the job, time pressures, targets, the consequences of mistakes, and family commitment constitutes some of the intrinsic factors that impose barriers to female under-representation in construction industry (Lingard and Francis, 2002; Loosemore and Waters, 2004; Lingard and Lin, 2004; Galea et al., 2015). The masculine nature of the construction industry, which is mostly characterized by its high levels of conflict and confrontational practices as well as its recruitment practices, has been known for some time to be a source of frustration for its female employees (Gale, 1994; Fielden et al., 2000; Fielden et 
al., 2001). Other factors include interruption of women's careers due to reproduction at certain times of their lives which also leads to gender discrimination (Lusa et al., 2009).

The construction sector according to Jahn (2009) has an extreme case of gender discrimination and lack of equal opportunities. The construction industry is one of the most male-dominated industries. Although researchers have shown that the performance ability of men and women in construction is at par and women can compete favourably when given equal opportunities (Ekesionye and Okolo, 2012). The industry has one of the highest percentages of gender discrimination (Amaratunga et al., 2003). Sang and Powell (2012) opined that women are under-represented in all construction occupations and professions. Fielden et al. (2000) reported that over 11 million women are employed in the UK, this account for half of the total workforce of the nation. However, the survey exposed that women constituted for only $13 \%$ of the construction industry's workforce. Low female participation in the construction industry has continuously been the trend globally. In Canada, the labour force survey showed that women constituted only $15 \%$ of the construction industry and only $10 \%$ in South Africa (Darlene et al., 2012; Jahn, 2009). Adeyemi et al. (2006) in a study revealed that approximately 16\% of the Nigerian construction industry workforce was women; this implies that construction workforce continues to be mostly male-dominated of all the major industrial groups.

The underrepresentation of women in the construction industry results from numerous barriers which exist in the industry. The subsistence of these obstacles affects women at three significant levels; at recruitment, retention and job progress (Sang and Powell, 2012). While the construction industry has had difficulties recruiting women, it refused to retain the women who find themselves in the industry. Issues of career progression are a topical issue as their male counterparts tends to progress faster in the industry than the females (Kaewsri and Tongthong, 2012). Khazenet (1996) opines that employers of labour in the construction sector should try to retain the number of women that enlist the construction industry to reduce their continuous departure from the industry by promoting equality of opportunities.

The number of female enrolments in construction-related courses such as engineering, architecture and other built environment fields in Nigeria tertiary institutions has witnessed a significant increase over the years. Kehinde and Okoli (2004) reported that these enrolments are more concentrated in courses requiring office work rather than fieldwork. However, the industry has not seen an equivalent change in the number of female participants, implying that the increase of female entrants into construction related courses in higher institutions does not automatically represent an increase in the number of women actively involved in their area of acquired expertise. Equal Opportunities Commission (EOC, 2006) published that despite women constituting approximately $50 \%$ of the UK population, more than $46 \%$ of the labour market and more than $50 \%$ of the entrants into higher education; they account for just $10 \%$ of the construction workforce.

Numerous questions have arisen as to the reason why female participants are fewer in the construction industry, whereas sectors such as nursing, banking, and even agriculture have seen women perform brilliantly despite rigours which may be involved in these other industries. Dainty et al. (2000) suggested that to keep hold of women; the construction sector requires a practical understanding of women's careers and what promotes their career progression in comparison to men's. This fact will allow the industry to formulate policies on how to develop human resources management (HRM) plan for a fair and equitable work environment and thus improve their retention in the future.

Further investigation is however required as to why this situation persists and how to improve female retention in the construction industry. However, this research is centred on investigating the barriers to female involvement in the Nigeria construction industry.

\subsection{Literature review}

\subsection{The construction industry skill shortage and need for women participation}

The viable construction sector is required for nation building. The Confederation of International Contractors' Associations (2002) reported that the built environment represents more than half of the 
total national capital investment while construction activities represent as much as $10 \%$ of GNP in developed and developing countries. The Nigeria Construction Industry is the largest employer of labour with over three million people working in the industry in different functions as practitioners (architects, quantity surveyors, planners, estate surveyors, land surveyors, engineers, and accountants), management staff, operatives, technical and labourers on construction sites. The construction industry contributes about $70 \%$ of the country's gross fixed capital and contributes about $3 \%$ to the gross domestic product (GDP). Construction output affects the economic activities positively, and other industrial activities revolve around the sector (National Bureau of statistics, 2015; Isa et al., 2013).

However, the industry is said to be facing potential skill shortages (Babatunde et al., 2012; Worrall et al., 2006; Campbell, 2006). Moir et al. (2011) stated that this skill shortage is due to an aging workforce, spontaneous retirements in the industry and other social reasons and economic factors which result to shortages of skilled labour in the trades. In addition to the skilled labour shortages, the shortage of female professional workers is even more striking, and these skill shortages/gaps need to be controlled on time so that the industry can progress (Bryer, 2010). To overcome the shortages of skilled workforce, there is a need for a stable, skilled, motivated and available workforce to meet up with these skill demands. The Equal Opportunities Commission (EOC, 2006) observes that underrepresentation of women in the construction sectors is fuelling skill shortages and solving this problem, studies have shown that employing more women will help solve the problem (Darlene et al., 2012). Babatunde et al., (2012) suggest that construction employers need to access a larger pool of talent from a broader range of people and gender for recruitment to develop a higher quality workforce that is optimally motivated and well-skilled to meet increasing construction needs.

For the construction industry to surmount the challenge of skill shortage/gap, solve the problem of an aging workforce and meet the future demands of the industry, more women undoubtedly need to be employed and encouraged to stay in the industry.

\subsection{Under-representation of females in the construction industry}

The statistics of construction labour force indicate that the construction industry is male-dominated; women are reluctant to join the workforce because they experience discrimination when they apply for a job or when in practice (Chun et al., n.d.). According to Munn (2014), there is continuously high enrolment of women undertaking full-time construction-related training in colleges in Britain and other European countries. This is an indication of the willingness of women to work in the industry, but they decline to progress further. There is, however, the perception that some women do not want to take courses in construction because of how the industry is perceived. The construction sector has always been known as a male-dominated industry. This problem is prevalent with the continued shortage of women within its workforce. The perspectives of the industry have not changed over the years, and the failure to contend with the damaging perception is what discourages some women from seeking for jobs within the construction industry (Arslan and Kivrak, 2004; Post, 2003).

Jahn (2009) found that the number of male workers compared to the female workers in the construction industry still varied in extreme amounts. This is as shown in Figure 1 were female workers only make up $10 \%$ of the total number of workers in the South African construction industry as of 2007. In the context of a developing country like Nigeria with a population of approximately 150 million people as of 2006; half of these are females (Fapohunda, 2012). The statistical strength of women demands that they be adequately represented in all facets of the economy of the country with particular emphasis on the construction industry which is one the prime motivators of any country's economic activities (Adeyemi et al., 2006). Tajudeen and Adebayo (2013) opine that Nigeria women have high potentials to improve the social and political landscape and hence transform the society better. Nevertheless, the construction industry has had a difficult time engaging women; in the UK for example, female constitute nearly $50 \%$ of the population, over $46 \%$ of the labour market, and over half of the total entrants into higher education, women are however responsible just $10 \%$ of the construction workforce (EOC 2006). 


\section{Male vs Female \%}

\author{
Female \\ $10 \%$
}

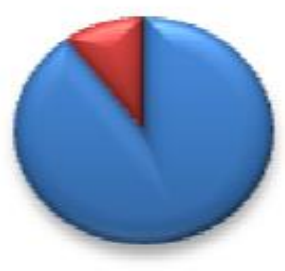

Male

$90 \%$

Figure 1: Percent of females to males in the South African Construction industry as at 2007 (Source: Jahn, 2009, p. 17)

Adeyemi et al. (2006) revealed that although female labour force represents about 50 percent of Nigeria's human resources, only $16.3 \%$ of the industry's workforce is women. Approximately half of these women are employed as labourers, $37.5 \%$ as secretarial staff, $10 \%$ as office staff and $2.5 \%$ as craftsmen. The National Bureau of Statistics (NBS, 2015) revealed that men make up more than $90 \%$ of the Nigerian construction workforce even though women constitute more than half the existing total workforce. The distribution of male employees in the sector between 2010-2012 shows that male employees represent $91.38 \%$ in 2010, 91.61\% in 2011 and $91.52 \%$ in 2012 (NBS, 2015).

Table 1 presents the employment by gender of the construction industry in Nigeria. From the table, there was an increase in the number Nigerian male employees for all three years while the number of females employed saw a reduction in their numbers by $0.45 \%$ between 2010 and 2011, but an increase by $6.10 \%$ for 2012 (National Bureau of statistics, 2015). This is the clear indication of apathy in the involvement of females in the construction sector in Nigeria.

Table 1: Employment size by gender in Nigeria construction industry 2010-2012

\begin{tabular}{|l|l|l|l|l|l|}
\hline \multirow{2}{*}{ Year } & \multicolumn{2}{|c|}{ Male } & \multicolumn{2}{c|}{ Female } & \multirow{2}{*}{ Total } \\
\cline { 2 - 5 } & Nigerian & Non-Nigerian & Nigerian & Non-Nigerian & \\
\hline 2010 & $5,861,845$ & 147,633 & 398,403 & 7,202 & $6,415,082$ \\
\hline 2011 & $6,065,033$ & 150,719 & 396,602 & 8,488 & $6,620,842$ \\
\hline 2012 & $6,327,377$ & 157,644 & 420,779 & 7,716 & $6,913,536$ \\
\hline Total & $18,254,255$ & 455,996 & $1,215,784$ & 23,406 & \\
\hline
\end{tabular}

\subsection{Methodology}

\subsection{Data collection}

Questionnaires were administered to respondents to elicit information on the involvement of females in the Nigeria construction industry directly by the researcher. The population for the survey is made up of the professionals in the Nigerian construction industry; the targeted stakeholder groups are the professionals in the building construction industry. Stratified random sampling technique was used in the choice of the sample size of the population to professionals in consulting and contracting organisations of the built environment in Lagos metropolis, Nigeria. Purposive sampling technique was used in administering the questionnaire to the professional as identified from the sample size. The study area was limited to Lagos metropolis in South-western Nigeria because about $65 \%$ of corporate head offices of consulting and contracting organisations were in this area and due to the time frame of the research work. 
The designed questionnaire was structured into two sections. The first section contained the title of the study and background information of the respondents, such questions as the type of organization, respondents' designation, academic qualifications, and work experience, marital status, and sex of respondents. The second section of the questionnaire related to objectives of this research which was to identify the barriers that lead to female underrepresentation in the Nigerian construction industry and to investigate if women are given equal opportunities in the Nigerian construction industry.

A total of 100 questionnaires were administered to the selected professionals. Out of the 100 respondents that were selected, 55 respondents completed the questionnaire reasonably, however, 14 questionnaires were rejected by the researchers for inadequate responses in the most critical section of the questionnaire; while 45 respondents did not return the questionnaire. Therefore, 41 questionnaires were found suitable and used for the analysis. These questionnaires were analysed with the use of Statistical Packages for Social Sciences (SPSS 16) using the statistical methods of average, percentage, mean score (MS).

\subsection{Results and Discussion}

This section discussed the findings of the study with respect to the barriers to female representation in the construction industry and the type of opportunities that exist by gender in the Nigerian construction industry.

\subsection{Barriers that lead to female under-representation in the Nigeria construction industry}

Table 2 presents the mean scores of the rankings of male and female respondents concerning barriers that influence female underrepresentation in the Nigerian construction industry. The male respondents agreed that the male dominance of the industry is the highest barrier with a mean score of 4.65 followed by family commitments. Masculine nature of the job both had mean scores of 4.13. The results of the female respondents agree with the response of the males as the male-dominated nature of the industry ranked the highest with a mean score of 4.7. While the female preference for some jobs other than jobs in the construction industry ranked second with a mean score of 4.3; family commitments, long working hours, Social-cultural perceptions and orientation about women not being as strong as men ranked third and fourth with mean scores of 4.2, 4.1 and 4.1 respectively.

The table further shows the mean score of both the males and females' perspective of the barriers in the industry. The male-dominated nature of the construction industry ranked the highest with a mean score of 4.66, followed by family commitments such as marriage and childbirth with a mean score of 4.15. The masculine nature of the job and long working hours ranked third with mean scores of 4.07 and 4.07 respectively; while lack of career progression, the poor image of the construction industry, lower pay than male counterparts for the same level of work ranked the least with mean scores of $2.95,2.85,2.78$, and 2.51 respectively.

The findings of this research revealed that the male-dominated nature of the industry ranked the highest which is similar to the result obtained by Olusola et al. (2012) where the male-dominance of the industry, as well as family commitment, ranked highest. The findings of Olusola et al. (2012) further revealed that the nature of the construction industry, gender discrimination, social-cultural perceptions and orientation ranked third, fourth and fifth respectively. On the other hand, the least ranked factors from their research were lack of career progression, reduced image of the construction industry, lack mentoring and recruitment policies and procedures which is similar to the findings of this study as fear of competition with men, lack of career progression, poor image of the construction industry and lower pay than male counterparts for the same level of work were the least barriers 
Table 2: Barriers to female participation in the Nigerian construction industry

\begin{tabular}{|l|c|c|c|c|}
\hline Identified Factors & $\begin{array}{c}\text { Male } \\
\text { Mean }\end{array}$ & $\begin{array}{c}\text { Female } \\
\text { Mean }\end{array}$ & $\begin{array}{c}\text { Overall } \\
\text { Mean }\end{array}$ & Rank \\
\hline Male dominance of the construction industry & 4.65 & 4.7 & 4.66 & $1^{\text {st }}$ \\
\hline Family commitments such as marriage and childbirth & 4.13 & 4.2 & 4.15 & $2^{\text {nd }}$ \\
\hline Masculine nature of the job & 4.13 & 3.9 & 4.07 & $3^{\text {rd }}$ \\
\hline Long working hours & 4.06 & 4.1 & 4.07 & $3^{\text {rd }}$ \\
\hline $\begin{array}{l}\text { Female preference of some jobs other than jobs in the construction } \\
\text { industry }\end{array}$ & 4.00 & 4.3 & 4.07 & $5^{\text {th }}$ \\
\hline $\begin{array}{l}\text { Social-cultural perceptions and orientation about women not being as } \\
\text { strong as men }\end{array}$ & 3.84 & 4.1 & 3.9 & $6^{\text {th }}$ \\
\hline $\begin{array}{l}\text { Negative stereotypes toward women mingled with the traditional belief } \\
\text { that construction is men's job }\end{array}$ & 3.65 & 4 & 3.73 & \multicolumn{2}{|c|}{$7^{\text {th }}$} \\
\hline Discriminatory recruitment practices & 3.52 & 3.3 & 3.46 & $8^{\text {th }}$ \\
\hline Discouragement due to male attitude & 3.19 & 3.2 & 3.2 & $10^{\text {th }}$ \\
\hline Salaries and wages when compared to other professions & 3.06 & 3.3 & 3.12 & $11^{\text {th }}$ \\
\hline Sexual harassment & 3.00 & 3.2 & 3.05 & $12^{\text {th }}$ \\
\hline Lack of family-friendly working environments. & 2.94 & 3.2 & 3 & $13^{\text {th }}$ \\
\hline Fear of competition with men & 2.87 & 3.2 & 2.95 & $14^{\text {th }}$ \\
\hline Lack of career progression & 2.71 & 3.3 & 2.85 & $15^{\text {th }}$ \\
\hline Poor image of the construction industry & 2.77 & 2.8 & 2.78 & $16^{\text {th }}$ \\
\hline Lower pay than male for the same level of work & 2.52 & 2.5 & 2.51 & $17^{\text {th }}$ \\
\hline
\end{tabular}

Hence, the agreement in the identified barriers given in this research work with findings in the past research work within Nigeria shows that the identified barriers which influence female underrepresentation in this research work are valid and are not just methodological manufactured fact.

\subsection{Equality of opportunities amongst male and females in the Nigerian construction industry}

Table 3 shows the responses given by the respondents to the questions asked on the number of employees and females in each respondent's organization. From the table a total number of five (5) respondents representing $12.2 \%$ indicated that there are $0-5$ number of employees in their organization, $2.4 \%$ indicated that there were $6-10$ employees and $70.7 \%$ of them indicated that the number of employees within their organization was above 20. The numbers of female in the respondents' organization were also revealed: the result shows that $4.9 \%$ of the respondents indicated that there are no female professionals in their organization. A large number of the respondents indicated that the number of females in their organization was in the range of 1-3 with a percentage of $63.4 \%$.

Furthermore, Table 3 presents another set of questions which the respondents were asked as shown with the responses given by each respondent. This section was analysed using frequency counts and mode. From the table, 26 respondents said 'Yes' to the question "do women in your organisation have equal chances of executing site related works as men", while a total number of 13 and 2 filled 'No' and 'Unsure' respectively.

The response 'Yes' also ranked the highest for questions such as "do women on the same cadre receive the same rate of salary as their male counterparts" and "are women likely to have a chance to get jobs equal to men on office related works." On the other hand, questions like "are women employed based on their marital status in your organization" and "are their policies in place for flexible working hours for women" had 'No' as their highest response. Hence, it can be concluded that equal opportunities exist for women in the construction industry as the majority of the respondent agreed to the statement on female opportunities. From the findings of the survey, although the percentage of female employers to their male counterparts is approximately $16 \%$, it was concluded that women in the construction industry are being accorded equal opportunities in the Nigerian construction industry. However, this finding is not in agreement with Madikizela and Haupt (2005) where a survey was carried out on the South African construction industry women. In the research, 94.1 percent of women said women do experience discrimination on the job in the construction industry while about 76.5 percent opine that this discrimination is more prevalent on construction sites than in consultancies films. 
Table 3: Equal opportunities for females in the construction industry

\begin{tabular}{|c|c|c|c|c|}
\hline Description & Range & & Frequency & $\%$ \\
\hline \multirow[t]{7}{*}{ Total number of employees in your current organization } & $0-5$ & \multicolumn{2}{|r|}{5} & 12.2 \\
\hline & $6-10$ & \multicolumn{2}{|r|}{1} & 2.4 \\
\hline & $11-15$ & \multicolumn{2}{|r|}{3} & 7.3 \\
\hline & $16-20$ & \multicolumn{2}{|r|}{3} & 7.3 \\
\hline & Above 20 & \multicolumn{2}{|r|}{29} & 70.7 \\
\hline & Total & \multicolumn{2}{|r|}{41} & 100 \\
\hline & Mean & \multicolumn{2}{|r|}{19} & \\
\hline \multirow{6}{*}{$\begin{array}{l}\text { How many female professionals are employed currently in your } \\
\text { organization }\end{array}$} & None & \multicolumn{2}{|r|}{2} & 4.9 \\
\hline & $1-3$ & \multicolumn{2}{|r|}{26} & 63.4 \\
\hline & 4-6 & \multicolumn{2}{|r|}{10} & 24.4 \\
\hline & Above 9 & \multicolumn{2}{|r|}{3} & 7.3 \\
\hline & Total & \multicolumn{2}{|r|}{41} & 100 \\
\hline & Mean & \multicolumn{2}{|r|}{3} & \\
\hline \multirow[t]{2}{*}{ Description } & \multicolumn{3}{|c|}{ Frequency } & \multirow{2}{*}{ Mode } \\
\hline & Yes & No & Unsure & \\
\hline $\begin{array}{l}\text { Do women in your organization have equal chances of executing site } \\
\text { related works as men? }\end{array}$ & 26 & 13 & 2 & Yes \\
\hline $\begin{array}{l}\text { Do women in the same cadre receive the same rate of salary as their } \\
\text { male counterparts? }\end{array}$ & 31 & 3 & 7 & Yes \\
\hline $\begin{array}{l}\text { Are women likely to have a chance to get jobs equal to men on office } \\
\text { related works? }\end{array}$ & 32 & 4 & 5 & Yes \\
\hline $\begin{array}{l}\text { Are there provisions for separate facilities for women employees e.g. } \\
\text { toilet, ablution, etc.? }\end{array}$ & 12 & 28 & 1 & No \\
\hline $\begin{array}{l}\text { Does your company have clear policy on non-discrimination when } \\
\text { hiring and training based on gender? }\end{array}$ & 11 & 13 & 17 & Unsure \\
\hline Are there policies in place for flexible working hours for women? & 8 & 25 & 8 & No \\
\hline Are women allowed to take maternity leave in your organization? & 34 & 3 & 4 & Yes \\
\hline $\begin{array}{l}\text { Are women employed based on their marital status in your } \\
\text { organization? }\end{array}$ & 7 & 27 & 7 & No \\
\hline $\begin{array}{l}\text { Does your company have explicit policy on non-discrimination when } \\
\text { hiring and training by sex? }\end{array}$ & 11 & 13 & 17 & Unsure \\
\hline
\end{tabular}

However, the findings of this research agree with Mohammaden (2013) which revealed that $66 \%$ of construction organisations accord women equal chance as men in office work, $48 \%$ allow women same chance as men in task work on site, $22 \%$ provide separate facilities to women, $48 \%$ of organisation do have distinct and clear policy on non-discrimination when hiring, training and gathering information on the basis of sex, $96 \%$ of organisations give females opportunities to get promoted within the structure of the company's organisation.

From the outcome of this study, if equal opportunities exist for both male and female, why is the high gap in the percent of female involvement to that of their male counterparts in the construction industry? This was revealed in this research as there is no flexibility in the working hours for female in the construction industry. From the study, women are not employed based on marital status, but the lack of flexibility in working hours for female can be responsible for the dearth in female participation. Women are mothers and homemakers, flexibility should be allowed in certain circumstances such as when pregnant as well as when nursing a new-born baby aside from the usual maternity leave, by so doing women might be encouraged to take up construction jobs.

Lack of clear-cut policies on gender discrimination during hiring is also viewed as an impediment to female representation in construction. The formulation recruitment policies that take away the dichotomy of gender disparity in the construction industry will stem the tide of female underrepresentation. 


\subsection{Conclusion and recommendation}

\subsection{Conclusion}

Females have continued to be mostly underrepresented in the Nigerian construction industry. This is seen in a typical construction firm; women are always fewer than men. This research sought to identify the barriers which lead to this underlying problem in the industry.

The summary of the findings of this study revealed that the perceived male-dominated nature of the construction industry and family commitments such as marriage and childbirth are responsible for the underrepresentation of female. However, it was established that there exists equal opportunity for both male and female in the industry but the lack of flexibility in working conditions is also an impediment to female entrants into the industry.

Discrimination during hiring does not promote equality because employers are mindful of the fact that women tend to go on maternity leaves during childbearing. They therefore, prefer males to their females' counterpart; nonetheless, if the female is more qualified or can perform as much as the male during recruitment. If employers can see women as of equal value as men, the issue of nondiscrimination concerning gender during recruitment will tend to improve female representation in the construction industry.

\subsection{Recommendations}

Grounded on the findings and the recommendations of respondents the following recommendations are put forward:

1) The government, construction professional bodies, and organizations should give sufficient attention to the challenges women face in the industry and employ adequate strategies to solve these problems.

2) Policies which ensure equal opportunities and prevent discrimination against women at recruitment should be enforced in construction organisations.

3) Women should be allowed flexible working conditions in certain circumstances such as when pregnant and during the nursing of their new baby after completing the standard maternity leave.

4) More women should be employed and encouraged to stay to bridge the skills shortage of the construction industry

\section{References}

Adeyemi, A. Y., Ojo, S. O., Aina, O. O. and Olanipekun, E. A. (2006). Some empirical evidences of inadequate representation of women in the Construction industry in Nigeria. Journal of Women in Management Review, pp. 567-577.

Amaratunga, D., Haigh, R., Lee, A., Shanmugam, M. and Elvitigala, G. (2003). Construction industry and women: A review of the barriers. 3rd International Scri Symposium, Delft University. 59-571. Netherlands.

Arslan, G. and Kivrak, S. (2004). The lower employment of women in the Turkish construction sector." Building and Environment, 39, pp. 1379-1387.

Babatunde. S. O., Babalola, O. and Opawole, A. (2012). An appraisal of career development among female professionals in the Nigerian construction industry. Global Journal of Research in Engineering, 12(2), pp. 1-10.

Campbell, F. (2006). Skills shortages in the Uk Construction industry. Available at http://www.ciob.org.uk [Accessed 3 September, 2018].

Confederation of International Contractors' Associations. (2002). Industry as a partner for sustainable development. Available at http://www.cica.net. [Accessed 3 September, 2018]. 
Dainty, A. R. J., Neale, R. H. and Bagilhole, B. M. (2000). Comparison of men's and women's careers in U.K. construction industry. Journal of Professional Issues in Engineering Education and Practice. 126(3), pp. 110-115.

Darlene, D., Joy, W., Gail, P. and Wanda, W. (2012). Women in non traditional occupations. ISBN 978-0-7785-6937-4. Available at http://www.alis.alberta.ca/publications [Accessed 2 September 2018].

Ekesionye, E. N. and Okolo, A. N. (2012). Women empowerment and participation in economic activities.indispensable tools for self-reliance and development of Nigerian society. Education Reseach and Review. 7(1), pp. 10-18.

EOC, (2006). Facts about men and women in Great Britain 2006. Equal Opportunities Commission. Available at http://webcache.googleusercontent.com [Accessed 10 July 2018].

Fapohunda, T. M. (2012). Women and the informal sector in Nigeria: Implications for development. British Journal of Arts and Social Sciences, 4, pp. 35-45.

Fielden, S. L., Davidson, M. J., Gale, A. W. and Davey, C. L. (2000). Women in construction: the untapped resource. Construction Management and Economics. 18, pp. 113-121.

Fielden, S. L., Davidson, M. J., Gale, A. and Davey, C. L. (2001). Women, equality and construction. Journal of Management Development. 20(4), pp. 293-304.

Gale, A. W. (1994). Women in non-traditional occupations: The construction industry. Women in Management Review. 9(2), pp. 3-14.

Galea, N., Powell, A., Loosemore, M. and Chappell, L. (2015). Designing robust and revisable policies for gender equality: lessons from the Australian construction industry. Construction Management and Economics, 33(5-6), pp. 375-389.

Isa, R., Jimoh, R., and Achuenu, E. (2013). An overview of the contribution of construction sector to sustainable development in Nigeria. Net Journal of Business Management, 1(1), pp. 1-6.

Jahn, M. (2009). Discrimination against women in the Construction industry in South-Africa

Kaewsri, N. and Tongthong, T. (2012). Professional development of female engineers in the Thai construction industry. In Social And Behavioral Sciences Symposium, 4th International Science, Social Science, Engineering and Energy Conference 2012.

Kehinde, J. O. and Okoli, O. G. (2004). Professional women and career impediments in the construction industry in Nigeria. Journal of Professional Issues in Engineering, Education, and Practice. 130(2), pp. 115-119.

Khazanet, V. L. (1996). Women in civil engineering and science: It's time or recognition and promotion. Journal of Proessional Issues in Engineering Education and Practice. 122(2), pp. 65-68.

Lingard, H. and Francis, V. (2002). Work-life issues in the Australian construction industry: Findings of a pilot study. Construction Industry Institute of Australia, Brisbane.

Lingard, H. and Lin, J. (2004). Career, family and work environment determinants of organizational commitment among women in the Australian construction industry. Construction Management and Economics, 22, pp. 409-420.

Loosemore, M. and Waters, T. (2004). Gender differences in occupational stress among professionals in the construction industry. Journal of Management in Engineering. 20(3), pp. 126-132. 
Lusa, A. M., Martínez, C., Calvet, C. D., Pons, O. and Tura, M. (2009). How to diagnose equal opportunities between women and men in organizations. Journal of Industrial Engineering and Management. 2(3), pp. 539-557.

Madikizela, K. and Haupt, T. (2005). Influences on women' s choices of careers in construction: A South African study. Australasian Journal of Construction Economics and Building Conference Series, 10(2), pp. 1-15.

Mohammaden, A. H. (2013). Factors affecting women career choice: comparison between civil engineering and other engineering disciplines. Ph.D. Thesis, The Islamic University - Gaza

Moir, S., Thomson, M. and Kelleher, C. (2011). Unfinished business: Buidling equality for women in the construction trades. Available at: http://Scholarworks.Umb.Edu/Lrc_Pubs/5. [Accessed 10 July 2018].

National Bureau of Statistics (2015). Nigerian construction sector summary report: 2010-2012. Available at http://www.nigerianstat.gov.ng/report/265. [Accessed 10 July 2018].

Post, N. M. (2003). Good ol'boys' start to talk the talk in support of women. Engineering News Record.

Powell, A. and Sang, K. J. C. (2013). Equality, diversity and inclusion in the construction industry. Construction Management and Economics, 31(8), pp. 795-801.

Sang, K. and Powell, A. (2012). Gender inequality in the construction industry: Lessons from Pierre Bourdieu. In: Smith, S.D (Ed.) Proceedings of 28th Annual ARCOM Conference, 3 - 5 September 2012, Edinburgh, UK, Association of Researchers in Construction Management, 237-247.

Shittu, A. A. and Shehu, M. A. (2010). Impact of building and construction investment on the Nigerian economy during the military era (1991-1998) and civilian era (1999-2006). Nigerian Journal of Construction Technology and Management. 11(1\&2), pp. 89-98.

Tajudeen, O. and Adebayo, F. (2013). Gender, economic activities and poverty in Nigeria. Journal of Research in Peace, Gender and Development, 2(7), pp. 106-125. 